Pedagogy and Psychology of Sport, Vol. 2 / No 2, 2016

Khomenko I. M., Zakladnaya N. V., p. 43-50

Received: 01.08.2016. Revised 12.09.2016. Accepted: 30.09.2016.

DOI:http://dx.doi.org/10.12775/PPS.2016.010

Original Text published (C) The Author (s) 2016.

Khomenko I. M., Zakladnaya N. V. Оцінка стану здоров'я дорослого населення зони спостереження Запорізької Атомної Електростанції = Evaluation of health status of adult population in the observation area of Zaporizhia Nuclear Power Plant. Journal of Education, Health and Sport. 2016;6(2):77-86. eISSN 2391-8306. DOI http://dx.doi.org/10.5281/zenodo.45847

http://ojs.ukw.edu.pl/index.php/johs/article/view/3379

УДК 613:614.876:340.13(477)

\title{
Evaluation of health status of adult population in the observation area of zaporizhia nuclear power plant
}

\section{Оцінка стану здоров'я дорослого населення зони спостереження запорізької атомної електростанції}

\author{
${ }^{1}$ I. M. Khomenko, ${ }^{2}$ N. V. Zakladnaya \\ ${ }^{1}$ I. М. Хоменко, ${ }^{2}$ Н. В. Закладна
}

\author{
${ }^{1}$ Shupyk National Medical Academy of Postgraduate Education, \\ ${ }^{2}$ Tokmak Interregional Administration of Sanitary and Epidemiological Service of Zaporizhia \\ Region \\ ${ }^{1}$ НМАПО імені П. Л. Шупика, \\ ${ }^{2}$ Токмацьке міжрайонне управління Держсанепідслужби у Запорізькій області
}

Keywords: nuclear power plants, radiation protection, observation area, morbidity of population

Ключевые слова: атомные электростанции, противорадиационная защита, зона наблюдения, заболеваемость населения

\begin{abstract}
Introduction. Exploitation of nuclear power plants (NPP) is accompanied by a specific radiation and nonradiation influence on the environment. That is why the detection of their influence on the health of adjacent areas residents is of great importance. Objective. To estimate health status of the population of observation area of nuclear power facilities of Ukraine on the example of Zaporizhia NPP. Materials and methods. System review, bibliographic, analytical and statistical methods are used in the research. Results. An increase in the disease incidences of the digestive system of the adult population was found in certain regions of Zaporizhia NPP observation area. Conclusions. In connection with further development of nuclear power
\end{abstract}


engineering and extension of nuclear power plants in Ukraine after the end of their operation lifetime and possible influence of adverse environmental factors during their exploitation for health of population dwelling on the observation area, the morbidity of population requires more detailed study and estimation.

\section{Реферат}

Введение. Эксплуатация атомных электростанций (АЭС) сопровождается как специфическим радиационным, так и нерадиационным воздействием на окружающую среду. Поэтому изучение их влияния на здоровье жителей близлежащих территорий является актуальным.Цель. Оценить состояние здоровья населения в зоне наблюдения объектов атомной энергетики Украины на примере Запорожской АЭС. Материалы и методы. Использованы системно-обзорный, библиографический, аналитический и статистический методы. Результаты. Установлен рост заболеваемости взрослого населения отдельных районов зоны наблюдения Запорожской АЭС болезнями органов пищеварения.

Выводы. В связи с перспективой дальнейшего развития ядерной энергетики и продления действующих АЭС после окончания проектного срока их эксплуатации в Украине и возможным воздействием вредных факторов при их эксплуатации на здоровье населения, проживающего в зоне наблюдения, заболеваемость населения требует более детального изучения и оценки.

Загальновідомо, що експлуатація АЕС супроводжується як специфічним - радіаційним забрудненням довкілля, так і нерадіаційним впливом таких факторів, як тепло (від теплових вентиляційних викидів в атмосферу та теплових скидів при роботі гідротехнічних споруд), хімічні речовини (ангідрид сірчистий, вуглецю окис, пил неорганічний $\left(\mathrm{SiO}_{2}-20-70 \%\right.$, азоту двоокис) на навколишнє середовище та здоров'я населення. Проблема виявлення зв'язків між факторами забруднення при експлуатації АEC на довкілля та станом здоров'я людей, які мешкають в зоні спостереження (3C), обумовлена значним антропогенним навантаженням на навколишнє природне середовище [1].

Запорізька AEC (м. Енергодар Запорізької області) потужністю 6 млн. кВт) $є$ найкрупнішою в Свропі. На ній працює 6 водо-водяних енергетичних ректорів (BВЕР). Вона є єдиною в країні АЕC, на якій відпрацьоване ядерне паливо зберігається на власних сховищах радіоактивних відходів. Крім того, вона вже є третьою в країні АEC, на ній закінчився проектний термін експлуатації енергоблоків (№ 1 - в 2014 р., № 2 - в 2015 р. й закінчується в 2016 р. - блока № 3, а в 2017 р. - блока № 4) та проводяться заходи щодо подовження терміну їх експлуатації. Постільки подовження терміну роботи АЕС в нашій країні ще не досліджувалося, вивчення здоров'я жителів 3С може бути використано в якості інформації щодо безпеки цього заходу в атомній енергетиці. Додатковим джерелом формування дозових навантажень на населення, яке проживає на території ЗС Запорізької AEC, є природні радіонукліди викидів Запорізької теплоелектростанції (ТЕС) та штучні радіонукліди ${ }^{90} \mathrm{Sr} \mathrm{i}{ }^{137} \mathrm{Cs}$ глобальних випадінь. У викидах та скидах Запорізької АЕС можуть міститися ${ }^{60} \mathrm{Co},{ }^{131}$ I та ін. в комбінації з природними радіонуклідами K-40, U-238, Th-232 та продуктами їх розпаду, що утворюються при роботі станції в режимі нормальної експлуатації. До них додаються радіонукліди глобальних випадінь та радіонукліди чорнобильського походження. До того ж населення прилеглих до АЕС територій може піддаватися дії чинників техногенно забрудненого навколишнього середовища $[2,3]$.

Метою роботи було оцінити стан здоров'я дорослого населення в зонах спостереження об’єктів атомної енергетики України на прикладі Запорізької АЕС. 
Об'єктом дослідження стала захворюваність дорослого населення, яке мешкає в ЗС Запорізької АЕС, хворобами органів травлення.

\section{Матеріали та методи дослідження}

Однією з найбільш вразливих систем організму людини в умовах проживання в ЗС AEC може бути система органів травлення. Це пов'язано 3 можливим надходженням шкідливих речовин в організм людини через шлунково-кишковий тракт. Тому в якості критерію можливого впливу за умов проживання в 3С ми взяли загальну захворюваність та захворюваність на хвороби органів травлення [4-6]. За Міжнародної класифікації хвороб (МКХ-10) це класи А00-Т98 (всі хвороби), К00-К93 - хвороби системи органів травлення та найбільш поширені в цьому класі виразка шлунку (К25.0-К25.8) та дванадцятипалої кишки (К26.0-К26.7), гастрит і дуоденіт (К29) й холецистит (К81). Досліджуваним населенням були дорослі у віці 18 років і старше. Термін спостереження - 11 років (2003-2013 рр.). Контролем було населення Токмацького району, який знаходиться за межами 3С.

Інформаційною базою для проведення аналізу була державна статистична звітність за формами МО3 України № 12 «Звіт про захворювання, зареєстровані у хворих, які проживають у районі обслуговування лікувально-профілактичного закладу». IIÏ узагальнювали за районами, по Запорізькій області та Україні в цілому.

Для визначення відмінностей між показниками захворюваності при зіставленні їх як у часі, так і просторі використовували критерій Ст’юдента [7].

Статистично вірогідними визнавали відмінності в рівнях захворюваності при ймовірності безпомилкового прогнозу 95\% і більше (тобто при ймовірності помилки менше $5 \%$, p $<0,05)$ [8]. Математико-статистичний аналіз проводили із використанням пакетів ліцензійних комп’ютерних програм SPSS, MS Excel.

\section{Результати досліджень та їх обговорення}

Як видно з табл. 1, у межах ЗС Запорізької АЕC розташовані м. Енергодар, чотири райони (Василівський, Великобілозерський, Запорізький, Кам’янка-Дніпровський) та 24 населених пункти. Кількість населених пунктів невелика. Кількість мешканців в ній сягає майже 112 тис. осіб. Якщо виходити з того, що середня чисельність населення в районах по країні складає 30 тис. осіб, то його чисельність в ЗС відповідає 3-4 адміністративним районам.

Таблиця 1

Межі територій та чисельність населення зони спостереження Запорізької АЕС, станом на 01.01. 2015 p.

\begin{tabular}{|l|c|c|c|}
\hline \multicolumn{1}{|c|}{ Території } & $\begin{array}{c}\text { Кількість } \\
\text { населених } \\
\text { пунктів всього }\end{array}$ & $\begin{array}{c}\text { 3 них в зоні } \\
\text { спостереження }\end{array}$ & $\begin{array}{c}\text { Чисельність населення } \\
\text { зоні спостереження }\end{array}$ \\
\hline м. Енергодар & 1 & 1 & 43435 \\
\hline Кам'янка-Дніпровський район & 18 & 15 & 33955 \\
\hline Великобілозерський район & 5 & 4 & 6652 \\
\hline Василівський район & 38 & 2 & 24872 \\
\hline Запорізький район & 70 & 2 & 111742 \\
\hline Всього & 132 & 24 & \\
\hline
\end{tabular}


Оглядовий аналіз свідчить, що захворюваність дорослого населення ЗС Запорізької AEC, крім м. Енергодар, характеризувалась тенденцією до зростання. Так, у Кам'янкаДніпровському районі в 2003-2013 pр. захворюваність населення зросла на 7,9\% (3 47710 у 2003 р. до 51512 на 100 тис. нас. у 2013 р.), у Великобілозерському - на 56,4\% (з 51045 у 2003 р. до 79824 на 100 тис. нас. у 2013 р.), у Василівському - на 16,9\% (з 55177 у 2003 р. до 64525 на 100 тис. нас. у 2013 р.), у Запорізькому - на 28,9\% (з 40461 у 2003 р. до 52184 на 100 тис. нас. у 2013 р.). В м. Енергодарі захворюваність навпаки мала тенденцію до зниження. Впродовж 2003-2013 рр. вона знизилась на 5,4\% (з 44906 до 42459 на 100 тис. нас.). В контрольному Токмацькому районі вона теж знижувалася. Статистичний аналіз свідчить (табл. 2), що у Великобілозірському та Василівському районах показники захворюваності у 2003-2013 роках були вірогідно $(\mathrm{p}<0,05)$ більшими у порівнянні 3 контролем.

Таблиця 2

\section{Рівні захворюваності дорослого населення зони спостереження} Запорізької АЕС, 2003-2013 рр., на 100 тис. осіб

\begin{tabular}{|c|c|c|c|c|c|c|}
\hline \multirow{2}{*}{ Території } & \multicolumn{4}{|c|}{ Захворюваність: } & \multirow{2}{*}{$\begin{array}{c}\text { Середнє } \\
\text { значення } \\
\mathrm{M} \pm \mathrm{m} \\
\mathrm{P}\end{array}$} & \multirow{2}{*}{$\begin{array}{c}\text { Зміни } \\
2013 \text { р. до } \\
2003 \text { р. (\%) }\end{array}$} \\
\hline & $2003 \mathrm{p}$ & 2013 p. & Min & Max & & \\
\hline м. Енергодар & 44906,7 & 42459,1 & $\begin{array}{c}41250,9 / \\
2012 *\end{array}$ & $\begin{array}{l}53929,4 / \\
2005\end{array}$ & $\begin{array}{c}47398,5 \pm \\
1291,2 \\
p>0,05\end{array}$ & $-5,45$ \\
\hline $\begin{array}{l}\text { Кам'янка- } \\
\text { Дніпровський район }\end{array}$ & 47710,2 & 51512,9 & $\begin{array}{c}38485,4 / \\
2008\end{array}$ & $\begin{array}{c}53853,0 / \\
2012\end{array}$ & $\begin{array}{c}45229,2 \pm \\
1530,8, \mathrm{p}>0,05\end{array}$ & 7,97 \\
\hline $\begin{array}{l}\text { Великобілозер-ський } \\
\text { район }\end{array}$ & 51045,6 & 79824,8 & $\begin{array}{l}41542,8 / \\
2008\end{array}$ & $\begin{array}{c}79824,8 / \\
2013\end{array}$ & $\begin{array}{c}56538,7 \pm \\
3929,6^{* *} \\
(\mathrm{p}<0,05)\end{array}$ & 56,38 \\
\hline Василівський район & 55177,3 & 64525,6 & $\begin{array}{c}52245,7 / \\
2004\end{array}$ & $\begin{array}{c}70372,8 / \\
2010\end{array}$ & $\begin{array}{c}59811,8 \pm \\
1663,2 * * \\
(\mathrm{p}<0,05)\end{array}$ & 16,94 \\
\hline Запорізький район & 40461,1 & 52184,7 & $\begin{array}{l}40150,7 / \\
2008\end{array}$ & $\begin{array}{l}65258,4 / \\
2011\end{array}$ & $\begin{array}{l}45939,6 \pm \\
2577,5, \mathrm{p}>0,05\end{array}$ & 28,97 \\
\hline $\begin{array}{l}\text { Токмацький район } \\
\text { (контроль) }\end{array}$ & 51531,9 & 42459,1 & $\begin{array}{r}39719,1 / \\
2010\end{array}$ & $51531,9 / 2003$ & $\begin{array}{c}45453,3 \pm \\
1310,3\end{array}$ & $-17,61$ \\
\hline
\end{tabular}

Примітка. * В знаменнику показано рік, у якому зафіксовано значення; ** - статистично вірогідно у порівнянні з контрольним районом

Як видно з даних рис.1 та табл. 3, рівні захворюваності на хвороби органів травлення (ХОТ) в ЗС Запорізької АЕС у більшості досліджуваних районів (Василівський, Великобілозерський, Запорізький райони та м. Енергодар) у 2003-2013 рр. були більшими рівнів контрольного Токмацького району й це перебільшення було статистично вірогідним $(\mathrm{p}<0,05)$. Тенденцією до зростання характеризувалась захворюваність на ХОТ в Кам'янкаДніпровському (на 96,5\%, 3 727,8 у 2003 р. до 1429,9 на 100 тис. нас. у 2013 р.) та в Запорізькому районах (у 1,34 рази, з 1057,0 у 2003 р. до 2475,2 на 100 тис. нас. у 2013 р.). У двох інших районах (Василівському та Великобілозерському), а також в м. Енергодар вона мала тенденцію до зменшення. Найбільш значущим виявилося зниження рівнів захворюваності на ХОТ дорослого населення ЗС Василівського району (на 54,1\%, 3 1501,8 у 2003 р. до 690,0 на 100 тис. нас. у 2013 р.). 


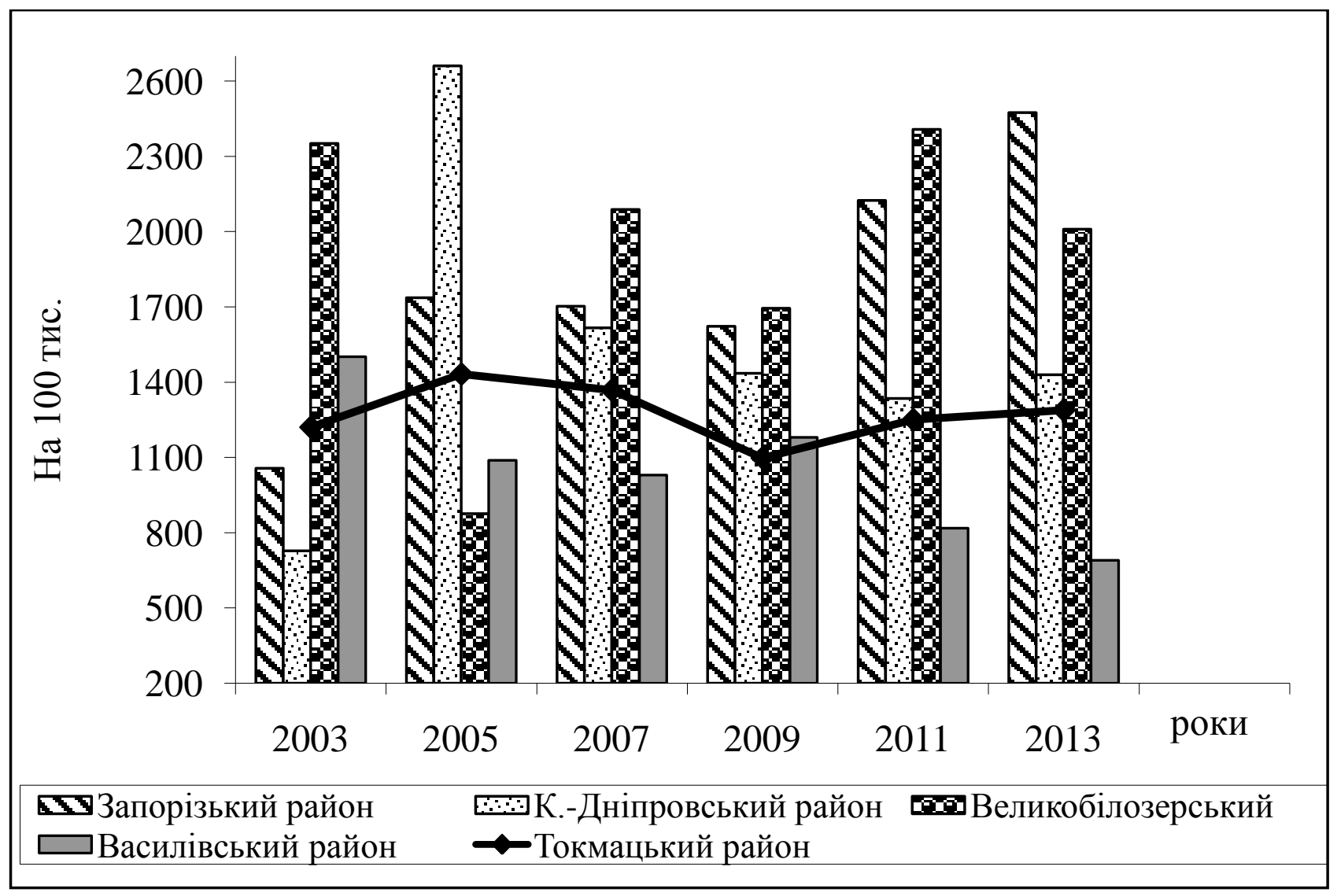

Рисунок 1. Захворюваність дорослого населення зони спостереження Запорізької АЕС та Токмацького району (контроль) на хвороби органів травлення, 2003-2013 pр., на 100 тис. осіб

Таблиця 3

Захворюваність дорослого населення зони спостереження Запорізької АЕС та Токмацького району (контроль) на хвороби органів травлення, 20032013 рр., на 100 тис. осіб

\begin{tabular}{|c|c|c|c|c|c|c|c|}
\hline Території & 2003 p. & 2005 p. & 2007 p. & 2009 p. & 2011 p. & 2013 p. & $\begin{array}{c}\text { Зміни } \\
2013 \text { р. до } \\
2003 \text { р. }\end{array}$ \\
\hline м. Енергодар & 455,1 & 625,3 & 404,1 & 296,7 & 262,1 & $291,6^{*}$ & $-35,93 \%$ \\
\hline Кам'янка-Дніпровський район & 727,8 & 2661,4 & 1616,9 & 1435,7 & 1335,4 & 1429,9 & $96,47 \%$ \\
\hline Великобілозерський район & 2352,1 & 876,1 & 2088,77 & 1694,9 & 2408,2 & $2010,1 *$ & $-14,54 \%$ \\
\hline Василівський район & 1501,8 & 1088,0 & 1029,5 & 1179,7 & 817,3 & $690,0 *$ & $-54,06 \%$ \\
\hline Запорізький район & 1057,0 & 1737,4 & 1703,3 & 1623,6 & 2125,6 & $2475,2 *$ & 1,34 рази \\
\hline Токмацький район (контроль) & 1219,9 & 1432,4 & 1368,1 & 1097,6 & 1249,9 & 1287,9 & $5,58 \%$ \\
\hline
\end{tabular}

Примітка. *-статистично вірогідно $(p<0,05)$ у порівнянні з контрольним районом

Аналіз показав, що найбільш поширеними в структурі захворюваності хворобами органів травлення були гастрити та дуоденіти, виразка шлунку та 12-палої кишки, холецистити та холангіти. Їх стан також було використано в оцінці здоров'я дорослого населення 3С Запорізької АЕС.

За нашими узагальненнями, у контрольному Токмацькому районі захворюваність на виразку шлунку та 12-палої кишки в досліджуваному періоді зменшувалася (на 38,8\%, 3 166,95 у 2003 р. до 102,12 на 100 тис. нас. у 2013 р.). Зменшувалась вона також у Кам'янкаДніпровському, Василівському районах та м. Енергодар. В той же час відзначалося зростання 
рівнів захворюваності на цю патологію у Великобілозерському (на 108,7\%, з 96,3 у 2003 р. до 201,03 на 100 тис. нас. у 2013 р.) та Запорізькому (на 16,2\%) районах.

Найбільш високі рівні захворюваності цією хворобою спостерігались у Великобілозерському районі, при цьому вони статистично достовірно перевищували аналогічні показники у контрольному Токмацькому районі $(\mathrm{p}<0,05)$.

У Великобілозерському районі виявлені також найвищі рівні захворюваності на гастрити та дуоденіти (табл. 4).

Таблиця 4

Захворюваність дорослого населення в Великобілозерському та

Запорізькому районі зони спостереження Запорізької АЕС на гастрити та дуоденіти, 2003-2013 рр., на 100 тис. осіб

\begin{tabular}{|c|c|c|c|c|c|c|c|}
\hline Території & 2003 p. & 2005 р. & 2007 p. & 2009 р. & 2011 р. & 2013 p. & $\begin{array}{c}\text { Зміни } \\
2013 \text { р. до 2003 p. }\end{array}$ \\
\hline Великобілозерський район & 281,5 & 214,6 & 535,9 & 648,9 & 1392,9 & 1019,5 & 3,6 рази \\
\hline Запорізький район & 311,72 & 423,84 & 395,81 & 368,51 & 542,57 & 624,16 & 2,0 рази \\
\hline Токмацький район (контроль) & 127,1 & 104,4 & 81,7 & 86,97 & 115,86 & 141,39 & $11,23 \%$ \\
\hline
\end{tabular}

Рівень захворюваності на цю нозологію збільшився у 3,6 рази (з 281,5 у 2003 р. до 1019,5 на 100 тис. нас. у 2013р.) і значно перевищував відповідні показники контрольного району $(\mathrm{p}<0,05)$. У 2 рази зріс рівень захворюваності дорослого населення гастрити та дуоденіти і у Запорізькому районі (з 311,72 у 2003р. до 624,16 на 100 тис. нас. у 2013p.) й воно також було статистично вірогідним $(\mathrm{p}<0,05)$.

\section{Висновки}

1. Встановлено, що з 2003 по 2013 рік відзначається зростання захворюваності дорослого населення окремих районів зони спостереження Запорізької АЕС на хвороби органів травлення.

2. 3 усіх досліджуваних районів найбільше зростання рівнів захворюваності на виразку шлунку та 12-палої кишки, гастрити та дуоденіти, холецистити, холангіти спостерігалось у Великобілозерському районі на 108,7\%, у 3,6 разів та на 63,4\%. В усіх випадках вони вірогідно перевищували контрольні показники $(\mathrm{p}<0,05)$.

3. Загалом отримані дані свідчать про необхідність подальшого здійснення медичного спостереження за станом здоров'я мешканців зон спостереження AEC для накопичення нових знань у зв'язку із здійсненням передбачених законодавством про зони спостереження заходів захисту людей й впровадженням подовження експлуатації АЕС після закінчення проектного терміну їх експлуатації. 


\section{Література}

1. Звіт про екологічний аудит ВП «ЗАЕС» [Електронний ресурс] - Режим доступу: http://www.npp.zp.ua/Content/docs/prolong/Zvit\%20pro\%20ekoaudit_VP\%20ZAES.pd f - Назва з екрану

2. Національна доповідь про стан техногенної та природної безпеки в Україні у 2012 році [Електронний ресурс] - Режим доступу: http://www.mns.gov.ua/files/prognoz/report/2012/3 1 2012.pdf - Назва 3 екрану

3. Прилипко В.А. Соціально-екологічні чинники у формуванні здоров'я населення зони спостереження атомних електростанцій [Текст] / В.А. Прилипко, О.О. Петриченко // Український Радіологічний Журнал. - 2014. - № 2. - С. 11-15.

4. Щорічна доповідь про стан здоров'я населення, санітарно-епідеміологічну ситуацію та результати діяльності системи охорони здоров'я України 2014p. / за ред. Квіташвілі О.; МОЗ України, ДУ «УІСД МОЗ України». - К., 2015. - 460с.

5. Брязкало В.В. Стан навколишнього середовища та його вплив на захворюваність населення України на національному рівні спостереження за результатами комп’ютерно-аналітичної програми «Медикопортал» розробленої в ДУ «ІГМЕ ім. О.М. Марзєєва АМНУ» [Текст] / В.В. Брязкало // Гігієна населених місць. - 2011. - № 58. - C. 421-429.

6. Січінава Р.М. Захворюваність за окремими класами і нозологічними формами осіб мобілізаційного резерву, евакуйованих у підлітковому віці у віддаленому періоді після аварії на ЧАЕС [Текст] // Вісник соціальної гігієни та організації охорони здоров'я України. -2015. - № 1(63). - С.31-34.

7. Александров О. О. Статистичний аналіз захворюваності населення України [Текст] / О. О. Александров, Ю. О. Ольвінська // Статистика - інструмент соціально-економічних досліджень : мат. конф. 2014-2015pp. - Одеса, ОНЕУ. - С. $32-36$.

8. Кобзарь А. И. Прикладная математическая статистика / А. И. Кобзарь. М.: Физматлит, 2006. - 816 с.

\section{References}

1. Zvit pro ekologichnij audit VP «ZAES» [Elektronnij resurs] - Rezhim dostupu: http://www.npp.zp.ua/Content/docs/prolong/Zvit\%20pro\%20ekoaudit_VP\%20ZAES.pd f - Nazva z ekranu

2. Nacional'na dopovid' pro stan tehnogennoï ta prirodnoï bezpeki v Ukraïni u 2012 roci [Elektronnij resurs] http://www.mns.gov.ua/files/prognoz/report/2012/3_1_2012.pdf - Nazva z ekranu

3. Prilipko V.A. Social'no-ekologichni chinniki u formuvanni zdorov'ja naselennja zoni sposterezhennja atomnih elektrostancij [Tekst] / V.A. Prilipko, O.O. Petrichenko // Ukraïns'kij Radiologichnij Zhurnal. - 2014. - \# 2. - S. 11-15.

4. Shhorichna dopovid' pro stan zdorov'ja naselennja, sanitarno-epidemiologichnu situaciju ta rezul'tati dijal'nosti sistemi ohoroni zdorov'ja Ukraïni 2014r. / za red. Kvitashvili O.; MOZ Ukraïni, DU «UISD MOZ Ukraïni». - K., 2015. - 460s.

5. Brjazkalo V.V. Stan navkolishn'ogo seredovishha ta jogo vpliv na zahvorjuvanist' naselennja Ukraïni na nacional'nomu rivni sposterezhennja za rezul'tatami komp'juterno-analitichnoï programi «Medikoportal» rozroblenoï v DU «IGME im. O.M. Marzeєva AMNU» [Tekst] / V.V. Brjazkalo // Gigiena naselenih misc'. - 2011. \# 58. - S. 421-429.

6. Sichinava R.M. Zahvorjuvanist' za okremimi klasami i nozologichnimi formami osib mobilizacijnogo rezervu, evakujovanih u pidlitkovomu vici u viddalenomu periodi pislja avariï na ChAES [Tekst] // Visnik social'noï gigieni ta organizaciï ohoroni zdorov'ja Ukraïni. -2015. - \# 1(63). - S.31-34. 
7. Aleksandrov O. O. Statistichnij analiz zahvorjuvanosti naselennja Ukrä̈ni [Tekst] / O. O. Aleksandrov, Ju. O. Ol'vins'ka // Statistika - instrument social'no-ekonomichnih doslidzhen' : mat. konf. 2014-2015rr. - Odesa, ONEU. - S. 32 - 36.

8. Kobzar' A. I. Prikladnaja matematicheskaja statistika / A. I. Kobzar'. - M.: Fizmatlit, 2006. -816 s. 